\title{
Importance of Culture and Art Journalism Education Today
}

\author{
Ceyda Ilgaz Büyükbaykal \\ Istanbul University, Istanbul, Turkey
}

\begin{abstract}
In modern-day society structure, every branch of art is presented to individuals and society with mass media. The impacts of mass media in the protection and improvement of cultural and artistic values cannot be denied in the society. By the courtesy of mass media, information is given to the society about the national and international activities in the scope of culture and art. The works, opinions and thoughts of artists can have access to the society. In this area, media becomes individual followers with the specialized journalists. In this context, to achieve the fulfillment of representation deficiency of culture and art in the media, to encourage dealing more frequently and qualitative way, to provide specialization in the scope of culture and art journalism and generalization of the same have importance. The purpose of our study is to transfer the importance of the education to be given in this field by emphasizing the importance of cultural and artistic works in social development.
\end{abstract}

Keywords: culture, arts, journalism

\section{Introduction}

Mass media has basic functions such as entertaining and to make use of the spare time of people along with informing the people. For example, they assume the function of relieving the individual with the activities such as theater, cinema, dance, music and sports having weightiness.

Mass media do not narrow the horizon of contemporary human experiences but on the contrary, mass media expand the same and increase self-expression possibilities for the modern man (Oskay, 1993, p. 15). Communication is a vital process. At the present time, also the cultural differences between the societies are becoming a bit more decreased by means of communication. Communication comes into existence together with the people and it provides continuity in the structure of the society. Continuity of the society inheriting its customs and traditions from one generation to another is based on the communication.

At the present time, many people make use of mass media with the purpose of being able to obtain information about the economic, social, cultural and political developments.

Individuals of different socio-economic and cultural classes in every society have considered the importance of communication throughout the centuries. Due to being in need of communication by the people, stunning developments are coming into view in this scope with each passing day. Developments and innovations in different communication devices from newspapers to television channels, from wireless units to radio transmitters, from laptop computers to video cell phones show the point reached by the humankind in this scope. (Büyükbaykal, 2003, pp. 185-186)

International cooperation and cultural exchange are realized by means of mass media. Mutual interaction between the societies in the fields of culture and art increases more by the courtesy of this. These instruments provide cultural continuity and at the same time, they have the ability to prepare the society to changing. In the

Ceyda Ilgaz Büyükbaykal, Associate Professor, Journalism Department, Faculty of Communication, Istanbul University. 
same breath, mass media have an important place in the protection of cultural heritage of the society they belong and to inherit the same to posterity.

Impacts of mass media cannot be denied in the protection and development of cultural and artistic values in the society. By virtue of mass media, information is given to the society about the national or international activities in the fields of culture and art. The works, standpoints and thoughts of the artists can be reached to the society.

Mass media are in the position of a culture carrier and transferor. At the present time, almost in every serious newspaper in Europe has a comprehensive page where interviews and discussions about the culture and art events take place in the same. Through these pages, communication established with the society gain continuity in terms of cultural standpoint. Consequently, it is very important in the western media to have specialization in the fields of culture and art. It is required for the correspondent doing reporting in this scope to be qualified and equipped in the sense of culture and art. In this context, Faculties of Communication must educate qualified journalists in this scope by giving importance to specialization.

\section{Overview to Culture and Art Concepts}

The first open and comprehensive definition about the concept of culture belongs to English Anthropologist Edward B. Tylor. Tylor defines the culture as the whole of knowledge, belief, art, law, tradition, custom and the habits and abilities gained by the person with living as a member of the society.

According to Tomlinson, culture can be seen as a standard of living tried to be built by the people through symbolic presentation practices (Tomlinson, 2004, p. 33). In a sense, culture narrates everything transferred and forwarded with social instruments. Wide using of the culture sometimes remains limited with the arts.

Together with the modernization process, an apparent polarization related to culture point of view is seen. This is the polarization between the approaches of keeping the culture limited with art, literature and intellectual competences with the approach having the identification of culture with all the people in the society. Here, keeping art and literature mainly limited with the occupation field of higher segments of the society has brought the situation for the culture to be seen as a field being inherent to high class (Güngör, 2011, p. 226).

Culture is a way of living and all expressions, interaction ways identical to a society take place in this definition. At the same time, culture is the form of perception, thinking and behaving. It also contains almost everything about our Daily living. Art is a production about life. It creates a meaning to the content by giving the shape to the words with various forms of expressions: colors, voices, and words.

Art, just like culture, is a concept having its existence in every period of the humankind and just like it; it has different interpretations in the definitions. Art means the creation of meaningful shapes freely and it gives form to our wishes and our perception for the world (Tanilli, 2006, p. 206).

Art is a social institution having

many areas, currents, museums, exhibition salons, applicators. The subject of "what is art" shows some differences according to ages, societies and field of art. In our day, even though art is widely used for the visual arts, definition has changed continuously throughout the centuries. In the beginning stages, it has been voluminously used in order to define all creative behaviors of human and probably, it was also containing breeding and survival of the humankind... "Art" is the English word defining all artistic activities. "Art" comes from the Latin word of "Ars" and it means "arrangement" or "to arrange". This is the one of the most fundamental definitions of the art. (Keser, 2005, p. 291)

Art is the most diversified and most creative one of the instruments for the individuals in the society to establish communication with each other. Imagination, aesthetics, creativity and talent take place within the art. 
Art is the phenomenon addressing to the feelings of the humankind and causes deep thoughts for them by giving some messages. Cave pictures in the primeval ages are also art. The ones made during Renaissance and Reform periods are art as well. Art works narrates as the trials, different dimensions we cannot see about life and encountered experiences.

Art is not a science field but it is a creation area and communication universe, which can work realistic or surrealistic. It cannot exist, cannot breath with rules and the rules kill it. For this reason, it never gives up from the search of autonomy and subjectivity (Aydın, 2009, p. 261). Art influences the lives of the individuals living in the society and society determines potential content and function of the art. Artist and the works done by him are at the point where this web merges (Baynes, 2004, p. 28). Art has always been open to improvement and change because it does not recognize strict rules and because of being liberal.

Art is the product of social life and its purpose is to shape the feelings, thoughts and excitements of human beings and to convey to the others. In one respect, it is the conveyance of human feelings. Humankind expresses himself through art, in a manner of speaking; it establishes communication with the other human beings. Art works narrate a certain existence and it symbolizes certain events. We can also see the art as the aesthetic relation between human being and objective realities in the nature and in reality; it exists from the beginning of humankind.

Art is the activity based on timeline of a person living the same feelings by perceiving the feelings reflected by another person by seeing or hearing it (Tolstoy, 2010, p. 49). Consequently, art is the instrument to transfer the feelings.

The most important one among the purposes of the art is substituting life and providing a balance between the humankind and his environment. It rescues the people from individualization and socializes them. It can succeed this by making us think that the life-styles we see in the others can be ours. It reflects the ability of sharing the feelings and thoughts. Regardless of the society, since a complete balance can never be provided between the human being and the environment he lives, art has been required by the societies in every period and it shall continue to be required. Function of arts shall change as the requirements and frames of mind of the societies change and it shall undertake new tasks. It shall help humankind to get over himself (Ersoy, 2002, p. 43).

Technological developments and social transformations also affect the function of the art. For example, classic art has become distant from its traditional line with modernism. Wide spreading of mass media has also affected art branches. In a manner of speaking, transformation taking place in the society during this period has laid the base of consumer society.

\section{Commodification of Culture and Art at the Present Time}

It is accepted that modern media image has become evident for the first time during the process of having the transformation of 18th Century's England to rural capitalist society. Artistic products were perceived as a commodity in those periods for the first time and a price of artistic-literary work came into existence. Concepts of books, newspapers, magazines, booksellers, mobile libraries, publicity magazines and publicities, journalists and the persons writing for money, best sellers concepts came into existence. With the rising of bourgeois classes, novel also comes into existence in this period. All of these are closely connected with the transformation of rural capitalist society and culture to an industrial urban capitalist society and culture. This transformation has provided material foundation and social organizing in second big stage of changing and 
expansion in "cultural production" distribution media. Third stage has coincided with the transformation to the stage called monopolistic capitalism with the transformation from the first stage of industrial capitalism to its second stage (Badioğlu, 2011, p. 79).

Culture industries have integrated with capitalism and they are media and entertainment companies. In the culture industries where media organizations step in, there is a culture devoted to artificial culture, entertainment and consumption. At that, cultural production has become a part of capitalist economy.

In the wide spread of consumer culture environment of late capitalism after the war, it has gained hedonism and technically fetishistic characteristic and especially after the 80 s when capital proceeded to attack and gained overwhelming upon all opposing factors, post-modern media indicators have dominated late capitalist culture and its logic by reification, commodification within the market mechanism with their prominent value to change. In the reality of our current society with port modern characteristic of cultural production, emphasizing of mass media has increased and historical and social meaning of them have changed. (Çakır, 2009, p. 15)

"According to Adorno, culture is not reificating art works produced by the culture industry, but they are the commodities produced for the market from the very beginning" (Dellaloğlu, 2007, p. 117). Standardization is one of the determinant characteristics of culture industry definition. Adorno argues that transformation of the art by popularizing with the purpose of entertainment makes it monotonous. In culture industry, human beings lose the position of being social object. Individuals realize the production process again by playing the roles attributed to them but not with their own free will and ideas.

Benjamin's wandering idle human being, in other words, flaneur concept has currently found its equivalent in digital flaneur who roams without standing up together with the facilities of technology. On the other hand, Flaneur's home Paris passages is digital flaneur's home of Internet and new media. Art viewer has become active within virtual environment and he has transformed to a participant completing the artwork with his experience (Torun, 2015, p. 7).

According to Walter Benjamin, it is the aura of the artwork that gives its authenticity. Reproductions of the artworks again and having the possibility to be reached by every segment of the society has moved the artwork away from its creator and this causes the loss of its aura. Benjamin, by indicating that every artwork is a ritual, emphasized that art's traditional viewing rituals are lost together with the using of new mass media technics (Benjamin, 2008). In the context of art's commercialization, for example: when it is thought that a famous composer's works are played and tickets are purchased by paying a certain price and the concert is realized during the determined hour and place, dying away of the artwork is in question together with the substantiality of the artwork. Having the activation of reproduction technics and especially together with the using of mass communication technology, art's traditional viewing rituals have started to get lost. At this point, art was transformed to the form of a commercial commodity that can be reproduced continuously.

According to Benjamin, breaking off the art from its extensive context, losing its rituals, dying away of its aura are the negative things... Benjamin prefers art's expansionist side with its lost authenticity rather than art's authentic monopolistic state. Even if this situation brings the art to the state of a continuously reproduced commercial commodity. According to the view point of Benjamin, even the most authentic Hollywood Film recording is not more valuable than the painting of a Vinci. However, film continuously gains value by depending on the ratings (Güngör, 2011, p. 162).

Against the change of technologic processes related to production and distribution of the artworks and reification of living, essence and nature of the artworks have changed. In 19th Century, many artists such as 
Charles Baudelaire have thought that the change occurring with the technical progress may have influence for the art in negative direction. "Here" and "Now" feelings give authenticity to artworks. Consequently, "aura" can be defined as the moral cover covering the human by coming out from the human or object and it exists in the nature and it takes shape with the authentic formation of an image belonging to any distance. This inaccessibleness is the basic characteristic of the "aura" of art products (Torun, 2015, p. 3).

\section{Culture and Art in Show Society}

At the present time, daily living is taking shape by the shows of the consumer society. From economy to culture, from sports to policy, media show has surrounded every area of our living. Consequently, culture and also art have become a part of the media show.

Show is not the total of images but it is a social relationship existing between the persons and passing from the mediation of the images (Debord, 2006, p. 40). It has become more convenient to access to artworks by means of globalizing media and developing technology and Internet. Cultural production is provided through serial reproduction in the current show society.

During the first periods of capitalism, while symbolic eras was separated from the economic area, all cultural areas have intertwined under the siege of media imperialism in the global culture industry era carrying the characteristics of show society and image. Also including the literature, all cultural production areas, communication systems carry the characteristics of this general tendency. At the present time, culture has become a media topic, every cultural area has been the subject of media by the conscience industry, and this has gained widespread feature (Çakır, 2009, p. 22).

Culture industry has increased by spreading media shows to new areas and show has become one of the rules arranging economy, management, society and daily life. Interned based economy is used as an instrument for the show, promotion, serial production, circulation and sales of products. Media culture produces technologically advanced shows in order to attract audience and increase the power and profit of the media. (Kellner, 2010, p. 19)

At the present time, media show has a significant place in giving shape to social and political life. In order to have the show culture reach commercial success, it needs to be entertaining. Consequently, emptied, unqualified artworks having the entertainment element in the forefront take more places in the media. In this context, if we give an example from the cinema films, even the introductions (trailers) of the films during the recent years are in the state of attention-grabbing shows. Dresses of the stars or with whom they have come to the premiere take precedence over the topic of the film.

Eco (2012, p. 195) mentions the point currently reached by the show society with a stunning example; why was a person coming from Bologna to Cattolica to listen a speech to last less than five minutes when the same person was also coming to university at the desired times throughout the year to listen to me free of charge (on top of that, when it is considered that this adventure also costs more than a theater show in terms of the money spent for the benzene, highway, dinner in order to come to Cattolica from Bologna)? There is a simple reply to this question: they were not coming to listen to me. They were coming to live the Event. They were coming also listen to the other persons and in order to take part in a collective activity. Is it for the sake of attending a show? I can answer this question as Yes without hesitation for a moment, without feeling any shame and any ailment.

According to Eco, not being missing from an activity attended by everybody is becoming an important factor is the show society. You become a part of the show society starting from the moment of this with the other people through the medium of social media. 
Cultural activities sometimes become a part of the show society. Especially, it is possible that we may come across with many samples of this in the social media. Starting from the moment of sharing the images with the others for the social activity people went, they are taking place there in order to share the event. Saying that "I was there", "I listened the concert of so-and-so or visited his exhibition" and displaying the same is becoming the most important element of the show society today.

\section{Culture and Art Journalism}

Professional Journalism ideology has come into view in the result of the change took place in the capitalization of the press throughout the 19th Century, in other words, with the transformation of the news into a commodity presented to the market. As the number of press enterprises increase in the media and media started to take place in the forefront with the power it has, interest for the journalists has increased even more. In addition, the changes and developments taking place in technology and communication world have caused new searches in the media and several arrangements have been done in the direction of these searches. One of these developments is vocational specialization. The fact of specialization in Professional Journalism ideology emphasizes that the news from politics to economy, in culture art, sports and judicial topics are prepared by the persons who make their correctness unarguable. This principle emphasizes that lined up news categories are the special areas and the specialists concentrated in their fields and same principle indicates that obtained privilege with their opinions and obtained skills in the result of a certain accumulation of knowledge and they use these furnishings in the direction of public welfare (Erdik, 2011, p. 60). At the present time, there are news taking place in the newspapers according to different interests and concerns. Accordingly, expertise is extremely important in the preparation of the news. Specialization in the press sector is also important from point of reputation in sectoral terms.

Culture art reporting is the area of specialization in presenting to readers/viewers all kinds of activities realized by the society within culture and art as the news. Development level of the society as a social infrastructure unit has direct proportion between the interest shown to cultural and artistic activities and development of culture art journalism.

Doing journalism in the field of culture is pleasure giving as much as it has difficulty. Its difficulty derives from its area containing considerably wide knowledge accumulation. There is the requirement to have knowledge in the basic areas such as archeology, art history, history, anthropology, sociology and fine arts. Journalist must be able to ask questions and he/she must know few of the basic information in order to be able to make research, otherwise it is almost impossible for him/her to put together an even seen by him/her and to be able to take out the news from it. At the same time, correspondent must have adequate level of intellectual accumulation in order to have the correct perception and transfer of the concepts.

For example when the correspondent working in the field of culture art forms the news of an exhibition visited by him/her first expresses his/her own observations. Together with his/her observations, he/she completes the news in the direction of the information obtained from the person or institution. Communication channels of the journalists between the institutions providing information to them must be open. Culture art correspondent must have connections with the leading establishments and institutions of this area such as the culture centers, universities, foundations and associations, ministry, local administrations, consulates and exhibitions.

Culture-art reporting contains the news covering every branch of the art such as literature, cinema, theater, music, plastic arts. By being different from the other pages, culture art pages also contains criticism articles 
about the events other than the special news. Because, receptive of culture art news waits for a positive/negative opinion about the topic and then decides whether to take place in the activity in the direction of this standpoint. For this reason, it is required for the correspondent who shall do the news in culture art news must be expert and competent in his/her field. He/she must not leave by only making the news of the event but he/she must be able to write commentary article about that event (Odyakmaz, 2013, p. 206).

If we have the newspaper in hand in the field of printed media from the mass media, there are pages taking place in the newspapers where there are only news, discussions and various topics only about culture and art events. Number of these pages shows difference according to types of the newspapers. As a matter of fact, it is also possible not being able to give place to this kind of pages in some of the newspapers. In the media organizations determined opinion journalism as the publishing identity, culture art services work with expert and dynamic staff. Page structure is increased to 2. While giving wide space to culture art activities, at the same time they enrich their pages with interpretations, critics and detailed interviews. Additionally, culture-art topic takes place in details also in newspaper's week-end supplements.

Journalists specialized in the area of culture and art are in advantageous position when compared with the journalists working in the other areas because they do not encounter an apprehension related with time. Since culture art agenda mostly becomes clearly beforehand, correspondent can spread his/her article to days. For example, the day of doing an exhibition or art fair is determined before, consequently correspondent has time to do the searches related with the topic. For this reason, journalists working in culture-art area have more comfortable working possibility.

\section{Importance of Culture and Art Journalism Education}

Culture and art has great importance in the development level of the societies. The States making a point for the education of the art which makes humankind human, art education, protection or the artworks, bringing up and support of the artists, providing the continuation of cultural activities, allocating a serious budget to culture by forming their cultural policies have respectability also in the international platform. As the societies progress, they spare less time to activities satisfying primitive egos and more time to activities satisfying intellectual liking.

In culture-art pages of the newspapers, activities, innovations related to activities for culture and art in national and international area and commentary articles related to topic take place together with the photographs. Literature, music, theater, cinema, painting, plastic arts, opera, ballet and even various auctions, etc. are the topic we can have the chance to meet in culture-art pages. Culture-art journalists assuming duty in the preparation of these pages generally follow the artistic and cultural activities arranged within the country and sometimes they follow the ones arranged abroad. By watching the activities such as exhibitions, festivals, concerts and theater, they transfer their opinions about these topics to their articles. Or they give the news called agenda activity by only containing the general information related to date, hour, place and the participants about the activity. In addition, journalists also pursue the changes taking place in culture and art policy of the government as well as the new laws and practices and they transfer them to their news. In general, they can also address the hitches and wrong attitudes taking place in culture-art policy and they can bring various proposals for the correction of them.

Like in every area, the need for the educated and trained labor force is gradually increasing also in the media area. However, vocational education is not the need only for the ones to be accepted to the vocation 
newly but at the same time it stands as an apparent need also with regard to the media employees accepted to the vocation in any way. Particularly journalism being in the first place, even though the opinions aimed at the requirement of certain education and training for the occupations taking place within the scope of media have dominancy, not accepting the fact of having education in the entry to the vocation as a precondition and also having the fact for the employment of persons having education in different levels from primary school to university generate an important issue (Altun, 2005, p. 76).

Without a doubt, importance of cultural and artistic sensibility is great in social development. In the current society structure, every branch of the art is presented to individual and society with mass media. In this area, media is becoming the follower with the specialized journalists. In this context, elimination of deficiency for the culture and art in the media and in order to encourage having the same in hand more frequently and in qualified way, providing the specialization in the scope of culture art journalism and generalizing it have importance (Erdik, 2011, p. 70).

It is expected that culture art correspondent must be specialist in one of the branches such as cinema, music, stage arts, literature, photography, architecture, and painting. In Turkey, we see that there is not a very serious specialization in the media; however, specialization in the area of culture and art is gradually increasing. Especially, in the media organizations adopted opinion journalism as the publication identity, culture art services work with an expert and dynamic staff. While Cumhuriyet newspaper allocates few pages to culture and art, newspapers such as Hürriyet, Milliyet give place to culture and art under the heading of Magazine. Culture and art are reached to the consumer by blending them with the magazine news. For example, the topic of the news about a cinema film coming to the theaters consists of the sensational scenes, starts and scandal news (if any) taking place in the trailer of the film rather than the message tried to be given by the film. In this process, while inside of the concept of "Art" is emptied and "Artist" concept is negated.

On the other hand, existence and activity area of culture and art journalism is extremely behind in our country when compared with the world standards. For example, when 10 thousand sales graphic is caught by Turkey's most demanding culture art magazine, Milliyet Sanat Dergisi (Milliyet Art Magazine) it is considered as a big success. Turkish Media mostly concentrates on the news of politics and economy. Culture-art news need a different reception and they have serious contents and for this reason, they are generally simplified by placing them inside of the magazine news and thus they become entertaining and can be consumed by everyone.

\section{Conclusion}

In various areas of journalism - economy, health, culture-art, etc.- specialization has importance in terms of the trustworthiness of the news. Perfection of the source of the news for the topic provides faster acceptance of the transferred information. News prepared by a journalist who is expert in his/her topic attracts more attention. Accordingly, specialization is very important in journalism. Specialization in this field is also important in terms of the institutional reputation of the media establishment.

When we look at the texts fictionalized by the media organizations about culture and art products, we can easily say that popular culture products are imposed as the reflection of the global culture and against this, products providing information and raising awareness as well as the opposing products to existing power groups are ignored. Whereas, our culture forms the entire common values and meanings belonging to us as well as art, as the carrier of it, are the keystones of our social awakening and togetherness. Although it is imaginariness to think that Turkish media can act separately from the global forces after being created after 
1980 and delivered to the hands of the capital at the present time, it is required to be aware of the situation with endeavor in the field of culture and art and awareness must be created especially by trying to see what is trying not to be seen (Odyakmaz, 2013, p. 205).

In the universities abroad such as Columbia, Lincoln and Missouri, educations are given in the scope of culture and art journalism and expert journalists are brought up in this area.

It is known that contemporary communication education in the world has first started in the year of 1908 in USA and in the School of Journalism established in Missouri University.

When we look at the culture-art pages of the newspapers particularly published in European countries, it is seen that the correspondents taking place in this area are specialized under the sub-headings of theater, literature, music, cinema, etc. On the other hand, in Turkey, specialization in this area shows development newly. A qualified culture art education must be configured according to continuously developing and changing conditions of our epoch. At the same time, individuals of the education to be given in this area must be directed to free and genuine thinking.

By considering the importance of becoming specialized in this context, Communication Faculties and Media Institutions must be in cooperation in terms of bringing up qualified persons. For the elimination of the deficiency for culture and art news in the media and in order to prepare the news in this scope in a more qualified way, it is extremely important to provide the specialization in the area of culture and art journalism.

Especially specialist fields of journalism must take place in the academic programs of Communication Faculties having increased numbers with each passing day and giving more graduates. Knowledge of the students must be provided in this area by giving lessons related to culture and art. Only then social conscience can improve in the topics related to culture and art. Requirement of education has become inarguable reality in the development of artistic and course of action.

\section{References}

Altun, A. (2005). YerelMedyaÇalışanlarınınEğitimİhtiyacıveYerelMedyaEnstitüsü (Educational needs of local media employees and local media Institute). Ankara ÜniversitesiIletişimFakültesiDergisi (pp. 75-104).

Aydın, M. Ç. (2009). SanatveSosyolojilliş̧kisiÜzerine, SanatlarveToplumsalEtkileşim (On the relationship between art and socialism: Arts and social interaction). İstanbul: E Yayınlar1.

Baynes, K. (2004). ToplumdaSanat (Art in society). İstanbul: YKY.

Benjamin, W. (2008). The work of art in the age of mechanical reproduction and other writings on media. Cambridge: Harvard University Press.

Büyükbaykal, G. (2003). IletişimvelletişimSürecininYaşamımızdakiYeri (Communication and the place of communication process in our lives). İstanbul: İ.Ü. BasımveYayınevi.

Çakır, S. (2009). Edebiyat, Imgelem, MedyaveToplum, SanatlarveToplumsalEtkileşim (Literature, imagery, media and society: Arts and social interaction). İstanbul: E Yayınları.

Debord, G. (1996). GösteriToplumu (Spectacle society). İstanbul: Ayrıntı.

Dellaloğlu, B. F. (2007). Frankfurt Okulu'ndaSanatveToplum. İstanbul: Say Yayınları.

Eco, E. (2012). GünlükYaşamdanSanata (From daily life to art). Trans: Kemal Atakay, İstanbul.

Erdik, M. B. (2011). Kent KültürüPerspektifindenKültür-SanatGazeteciliği: Kent DergisiÖrneği (Culture-art journalism from the perspective of urban culture: A study on Kent Journal) (Unpublished Master's Thesis, EgeÜniversitesiSosyalBilimlerEnstitüsü, İzmir).

Ersoy, A. (2002). Sanat Kavramlarına Giriş (Introduction to the concept of art). 3 Bask1, İstanbul, Yorum Sanat Yayıncıl1k.

Güngör, N. (2011). Illetişim, Kuramlar, Yaklaşımlar (Communication: Theories, approaches). Ankara, Siyasal Kitabevi.

Kagan, M. (1993). EstetikveSanatDersleri (Aesthetics and art lessons). Çev: Aziz Çalışlar, Ankara, İmgeKitabevi.

Kellner, D. (2010). MedyaGösterisi (Media spectacle and a stolen election). Çev: ZeynepPaşalı, İstanbul, Aç1lımKitap. 
Keser, N. (2005). SanatSözlüğü (Dictionary of arts). Ankara, ÜtopyaYayınc1lık.

Odyakmaz, N. (2013). Popüler Kültürün Yansıması: Kültür-Sanat Gazeteciliği (Reflection of popular culture: Culture-art journalism). İstanbul: Literatürk Yayınevi.

Oskay, Ü. (1993). Kitle İletişiminin Kültürel İşlevleri (Cultural Functions of Mass Communication). İstanbul: Der Yayınları.

Tanilli, S. (2006). Yaratıcı Aklın Sentezi (Synthesis of creative mind). İstanbul: Alkım Yayınevi.

Tolstoy, L. N. (2010). SanatNedir? (What is Art?). Baskı, İstanbul, TürkiyeİşBankasıKültürYayınları.

Tomlinson, J. (2004). KüreselleşmeveKültür (Globalization and culture). Çev: ArzuEker, İstanbul, AyrıntıYayınları.

Torun, A. (2015). SanatEserininAurasiveYeniMedyaSanatı (Aura of works of art and the art of new media). Retrieved from https://www.aasrc.org/imaj 